\title{
NIH agrees to temporary by-pass of AIDS office in allocation of grants
}

Washington. The US National Institutes of Health $(\mathrm{NIH})$ has made a preliminary decision to remove control over $\$ 1.4$ billion in spending on AIDS research during the current fiscal year from its embattled Office of Aids Research (OAR), and to channel the money directly to its institutes instead.

A spokesperson for Harold Varmus, the director of NIH, said on Monday that the biomedical agency took this decision last week. "We believe it was the best reading of the law," says Anne Thomas, although adding that Varmus was still "behind the OAR and its authority".

The decision was taken by NIH officials after consulting with the Department of Health and Human Services (HHS), of which the NIH is a part. NIH officials say that the agency, four months into the financial year and facing thousands of researchers still waiting to receive grants after two government shutdowns, was forced to take the decision to get its funding back on track.

But Clinton administration officials are still insisting that the decision is not final, and that the OAR will ultimately keep its responsibility for distributing to the NIH's 24 institutes and centres what amounts to 12 per cent of the NIH's $\$ 11.9$ billion 1996 budget. "We are not yet done with this issue," said a spokesman for the White House's National Aids Policy Office, adding that President Clinton is "absolutely and firmly" committed to maintaining the budgetary responsibilities of the AIDS office.

But Anthony Fauci, head of the National Institute of Allergy and Infectious Diseases, the top recipient of AIDS research money

receiving about 42 per cent of the total, said that for the present the OAR will be bypassed. "The decision at this point is to go ahead with [circumventing the OAR]," he said last Friday, 2 February. The director of the OAR, William Paul, could not be reached for comment, and his office did not return telephone calls this week.

AIDS activists complain that the decision, if made final, would emasculate the 33-member office, responsible for overseeing and coordinating AIDS research at the NIH. Its most immediate impact, they say, would be to consign to obscurity the recommendations that are due to emerge shortly

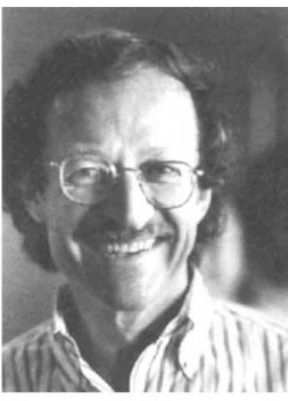

Varmus: AIDS research review expected soon. from a broad review of the NIH's AIDS research.

The study, which is to be released in March, has involved over 100 scientists and activists, and is expected to recommend fundamental changes in AIDS research at NIH. If OAR's authority to direct money is removed, "the report becomes a toothless tiger you can bury in a library somewhere", says one researcher.

The current controversy over the role of the AIDS office stems from a vote by the Republican-dominated House of Representatives in August to remove OAR's role in directing research funds to the various $\mathrm{NIH}$ institutes - a role that individual institute

\section{Rockefeller biologist tipped for the top at Salk}

Washington. James Darnell, a prominent molecular biologist who is head of the laboratory of molecular cell biology at Rockefeller University, New York, is being tipped to succeed Francis Crick as president of the Salk Institute in San Diego, California.

According to colleagues at Rockefeller, Darnell has been offered the Salk presidency, and is expected to decide whether to accept it this week. But neither the Salk Institute, nor Darnell himself, would confirm that the offer had been made. Anita Weld, a spokeswoman for the Salk, would say only that a search for a president is still in progress, led by Frederick Rentschler, vice chairman of the Salk board of trustees.

Crick, who won the Nobel prize with James Watson for the discovery of the double helical structure of DNA, stood down last August after undergoing a heart bypass operation, but remains on the faculty there.

Sources at Rockefeller say that Darnell, who is best known for his work on cell signalling and gene expression, was meeting this week with Torsten Wiesel, president of the university, before deciding whether to make the move. Many hope he will turn down the offer; Darnell has been responsible for managing junior faculty at Rockefeller, and 20 of them have written to Wiesel asking him "to do everything possible to keep Jim here at the university".

The Salk Institute, which was established by Jonas Salk, the polio vaccine pioneer, in 1960, now has 50 faculty members and a total of 500 staff engaged in biomedical research, especially in molecular biology, genetics and neuroscience. Colin Macilwain directors are known to resent.

A companion measure in the Senate retained the office's funding role. But neither bill became law, while a temporary measure approved recently, funding the $\mathrm{NIH}$ up to the end of September, is ambiguous as to whether the AIDS money should be distributed through the OAR, or go directly to the institutes.

While Varmus's office indicated that the NIH had decided on circumventing the OAR, officials in HHS and the Office of Management and Budget say that they are still working with the NIH to interpret the temporary spending measure, and to reach a final decision on whether to by-pass the OAR. "The administration is committed to an independent office of AIDS research, and is working to fix the perception problems that have arisen," says Victor Zonona, a spokesman for HHS.

AIDS activists say they were assured last week that the administration would not allow the OAR to be by-passed. Mark Harrington, a spokesman for Treatment Action Group, a New York AIDS activist group, says the group was "shocked" by the NIH's preliminary decision. He claimed Varmus had promised "many times" that support for OAR was "one of his highest priorities".

But Republicans in the House say the OAR should lose its funding role. A spokesman for John Porter (Republican, Illinois), chair of the appropriation subcommittee responsible for the NIH budget, says the full committee believes that "science, not politics, should make all judgements about scientific research". His subcommittee was largely responsible for boosting the NIH's 1996 funding by 5.7 per cent, which some feel has made Varmus loathe to risk alienating Porter by protecting the OAR.

The relevant bill already approved by the House specifies that AIDS research money must be funnelled directly to NIH institutes, the top two recipients being the National Institute of Allergies and Infectious Diseases and the National Cancer Institute.

Some point out that by-passing the OAR contravenes 1993 legislation that put the power to disburse AIDS research money in the hands of the office, which is strongly supported by AIDS activists. They say that it plays a crucial role coordinating AIDS research and avoiding duplication and waste. But conservative Republicans call the office, which was founded in 1988, a political interference in science by liberal Democrats who count the bulk of AIDS patients in their own constituencies.

Meredith Wadman 